\title{
Application and Performance of Artificial Intelligence Technology in Oral Cancer Diagnosis and Prediction of Prognosis: A Systematic Review
}

\author{
Sanjeev B. Khanagar 1,2 ${ }^{\mathbb{D}}$, Sachin Naik ${ }^{3}$, Abdulaziz Abdullah Al Kheraif ${ }^{3}$, Satish Vishwanathaiah ${ }^{4} \mathbb{D}$, \\ Prabhadevi C. Maganur ${ }^{4}$ (D), Yaser Alhazmi ${ }^{5}$, Shazia Mushtaq ${ }^{6}$, Sachin C. Sarode ${ }^{7}$ (D), Gargi S. Sarode ${ }^{7}$, \\ Alessio Zanza ${ }^{8}$ (D) Luca Testarelli $^{8}$ (D) and Shankargouda Patil ${ }^{5, *(\mathbb{D}}$
}

Citation: Khanagar, S.B.; Naik, S.; Al Kheraif, A.A.; Vishwanathaiah, S.; Maganur, P.C.; Alhazmi, Y.; Mushtaq, S.; Sarode, S.C.;

Sarode, G.S.; Zanza, A.; et al. Application and Performance of Artificial Intelligence Technology in Oral Cancer Diagnosis and Prediction of Prognosis: A Systematic Review. Diagnostics 2021, 11, 1004. https:// doi.org/10.3390/diagnostics11061004

Academic Editor: Jae-Hong Lee

Received: 2 May 2021

Accepted: 29 May 2021

Published: 31 May 2021

Publisher's Note: MDPI stays neutral with regard to jurisdictional claims in published maps and institutional affiliations.

Copyright: (c) 2021 by the authors. Licensee MDPI, Basel, Switzerland. This article is an open access article distributed under the terms and conditions of the Creative Commons Attribution (CC BY) license (https:/ / creativecommons.org/licenses/by/ $4.0 /)$.
1 Preventive Dental Science Department, College of Dentistry, King Saud Bin Abdulaziz University for Health Sciences, Riyadh 11481, Saudi Arabia; sanjeev.khanagar76@gmail.com

2 King Abdullah International Medical Research Center, Ministry of National Guard Health Affairs, Riyadh 11481, Saudi Arabia

3 Dental Biomaterials Research Chair, Dental Health Department, College of Applied Medical Sciences, King Saud University, Riyadh 11433, Saudi Arabia; snaik@ksu.edu.sa (S.N.); aalkhuraif@ksu.edu.sa (A.A.A.K.)

4 Department of Preventive Dental Sciences, Division of Pedodontics, College of Dentistry, Jazan University, Jazan 45142, Saudi Arabia; drvsatish77@gmail.com (S.V.); prabhadevi.maganur@gmail.com (P.C.M.)

5 Department of Maxillofacial Surgery and Diagnostic Sciences, Division of Oral Pathology, College of Dentistry, Jazan University, Jazan 45142, Saudi Arabia; dr.y.alhazmi@gmail.com

6 College of Applied Medical Sciences, Dental Health Department, King Saud University, Riyadh 12372, Saudi Arabia; smushtaqdr@gmail.com

7 Department of Oral and Maxillofacial Pathology, Dr. D.Y. Patil Dental College and Hospital, Dr. D. Y. Patil Vidyapeeth, Pimpri, Pune 411018, India; drsachinsarode@gmail.com (S.C.S.); gargi14@gmail.com (G.S.S.)

8 Department of Maxillo and Oro-Facial Sciences, University of Rome La Sapienza, 00185 Rome, Italy; ale.zanza@gmail.com (A.Z.); luca.testarelli@uniroma1.it (L.T.)

* Correspondence: dr.ravipatil@gmail.com

Abstract: Oral cancer (OC) is a deadly disease with a high mortality and complex etiology. Artificial intelligence (AI) is one of the outstanding innovations in technology used in dental science. This paper intends to report on the application and performance of AI in diagnosis and predicting the occurrence of OC. In this study, we carried out data search through an electronic search in several renowned databases, which mainly included PubMed, Google Scholar, Scopus, Embase, Cochrane, Web of Science, and the Saudi Digital Library for articles that were published between January 2000 to March 2021. We included 16 articles that met the eligibility criteria and were critically analyzed using QUADAS-2. AI can precisely analyze an enormous dataset of images (fluorescent, hyperspectral, cytology, CT images, etc.) to diagnose OC. AI can accurately predict the occurrence of OC, as compared to conventional methods, by analyzing predisposing factors like age, gender, tobacco habits, and bio-markers. The precision and accuracy of AI in diagnosis as well as predicting the occurrence are higher than the current, existing clinical strategies, as well as conventional statistics like cox regression analysis and logistic regression.

Keywords: artificial intelligence; artificial neural networks; oral cancer diagnosis; machine learning; oral cancer prediction

\section{Introduction}

Oral cancer $(\mathrm{OC})$ is one of the most common lethal diseases and has been a major public health concern around the world. OC is a subdivision of head and neck cancers with 275,000 fresh cases per year worldwide. The survival rate of the early stage (Stage I) disease is around $80 \%$, whereas for the late stage disease (Stage II and III), it is less than $20 \%[1,2]$. 
Among OC, squamous cell carcinoma (OSCC) of the oral cavity is the most common type and comprises $90 \%$ of the disease [3]. Early diagnosis of OC is significant, however, most patients are diagnosed at a late stage of the disease, leading to a poor prognosis. The clinical appearance of $\mathrm{OC}$ is not a sufficient parameter for identifying the status, analysis, or dysplastic level, therefore, the treatment selection based on the clinical appearance of the disease is not sufficient. OC is associated with multiple factors, and the survival rate after treatment is also unpredictable $[4,5]$.

Potentially malignant lesions like leukoplakia, erythroplakia, and oral submucous fibrosis are also prevalent among the risk population. Differentiating these lesions from the malignant lesions are also important. Risk factors like age, gender, and tobacco habits may affect the prognosis of OC [6].

Understanding the refinements of innovations like Artificial Intelligence (AI) could relieve potential clinical entanglements [7,8]. Application of AI in the oral malignant growths can improve the current challenges in the disease diagnosis, as well as in predicting the prognosis. AI, which mimics human cognitive functions, is a forward leap in innovation, and has enamored the minds of scientists over the globe [9]. Its use in dentistry has begun recently, which has led to extraordinary accomplishments. History goes back to as early as $400 \mathrm{BC}$; Plato visualized an essential model of brain function. AI system is a framework that takes $\mathrm{u}$ information, discovers designs, uses data to train itself, and yields results [9-11].

AI works in two phases-the first phase, which involves "training" and the second phase which is "testing". The model set uses the training data to set the parameters. The model uses the data from past examples, like data from patients or data with different examples, retrospectively. These parameters are then applied on the test sets. Various studies that have described the prognostic factors of OC are detected through AI by different biomarkers. Early diagnosis of the malignant lesion is good for patient survival rate and proper treatment therapy [12-16]. Many studies have been conducted using image analysis to smartphone-based OC detectors, based on AI algorithms. The AI technology facilitates the diagnosis, treatment, and management of patients with OC. AI reduces workload, complex data, and fatigue among physicians, for easy diagnosis [4,17]. The present systematic review intends to report on the application and role of AI-based technology in diagnosis and prediction of OC occurrence.

\section{Materials and Methods}

\subsection{Search Strategy}

In this systematic review, we followed the guidelines given by preferred reporting items for systematic reviews and meta-analyses extension, for the diagnostic test accuracy (PRISMA-DTA) [18]. Data search was mainly carried out through an electronic search in several renowned databases, which mainly included PubMed, Google Scholar, Scopus, Embase, Cochrane, Web of Science, and the Saudi Digital Library for articles that were published between January 2000 to March 2021. Index words like "artificial intelligence; oral cancer diagnosis; oral cancer prediction; oral cancer prognosis; deep learning; and machine learning" were used for searching the articles. Boolean operators (AND, OR) with language filters for English were used for searching articles in most electronic databases.

Simultaneously, a manual search for the research articles was also conducted along with the electronic search. A search for articles was carried out for the relevant citations from the reference list of previously retrieved articles in department and college libraries, where hard copies of the journals were available.

$\mathrm{PICO}$ (problem/patient, intervention/indicator, comparison, and outcome) elements were used for searching data on this topic (Table 1). 
Table 1. Description of the PICO ( $\mathrm{P}=$ Population, $\mathrm{I}=$ Intervention, $\mathrm{C}=$ Comparison, $\mathrm{O}=$ Outcome) elements.

\begin{tabular}{ll}
\hline Research question & $\begin{array}{l}\text { What are the applications and performance of the artificial intelligence models that have been widely } \\
\text { used in oral cancer diagnosis, and predicting the prognosis. }\end{array}$ \\
\hline Population & Patients, clinical images, radiographs, datasets, and histological images. \\
\hline Intervention & AI-based models for oral cancer diagnosis and predicting prognosis. \\
\hline Comparison & Expert opinions and reference standards. \\
Outcome & $\begin{array}{l}\text { Measurable or predictive outcomes such as accuracy, sensitivity, specificity, ROC = Receiver } \\
\text { Operating Characteristic curve, AUC = Area Under the Curve, ICC = Intra-class Correlation } \\
\text { Coefficient, PPV = Positive Predictive Values, and NPV = Negative Predictive Values. }\end{array}$ \\
\hline
\end{tabular}

\subsection{Study Selection}

The electronic database search yielded 620 articles that were followed by hand searching, which yielded another 8 articles, which made a total of 628 articles. Initially, the articles chosen were based on relevance in the area of research, the title, and the abstract. Later, the articles were also manually checked for duplication by 2 members who were not involved in the preliminary search, which further eliminated 288 duplicated articles. Following this, 340 full-text articles were selected for data selection. The following eligibility criteria were applied at the next stage.

\subsection{Inclusion and Exclusion Criteria}

The articles were included according to the following inclusion criteria-(a) the article must be original research and must report on the AI technology; (b) quantifiable values that can be evaluated/analyzed should be mentioned in the article; and (c) the data used in evaluating these AI-based models should be mentioned. There was no limit set for the study design for inclusion in this systematic review.

The articles excluded were-(a) the articles in which AI innovation were not mentioned; (b) unpublished articles or conference papers that were uploaded online; (c) articles where full-text versions were not available; and (d) articles available in languages other than English.

\subsection{Data Extraction}

After applying the inclusion criteria, we filtered 12 articles out of the total. These 12 articles were considered to be potentially eligible articles for this systematic review, and were critically analyzed by the entire team. The details of the journal were covered before circulating them for critical analysis among authors. The QUADAS-2 tool was used for assessing the quality of the studies reporting on diagnostic accuracy. It has four domains which are assessed in terms of risk of bias and applicability concerns. The domains are patient selection, index test, reference standard, and flow and timing [18]. The authors disagreed with including 3 articles in this systematic review, as there was no mention of the reasonable data supporting the results and conclusions. Following this, the articles were further reduced to 16. The selection of the articles for qualitative synthesis for this systematic review is represented in the flow chart (Figure 1). The articles were further quantified with regards to the year of publication, to report on the trends in research that has been conducted on OC diagnosis and the prediction of prognosis, using the AI technology. 


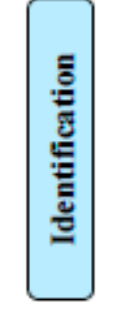

\section{Records identified through database searching} $(n=620)$

PubMed ( $\mathrm{n}=318)$, Google scholar $(\mathrm{n}=88)$, Web of science $(n=106)$, Scopus $(n=68)$, Embase $(\mathrm{n}=18)$,

Saudi Digital Library $(\mathrm{n}=22)$
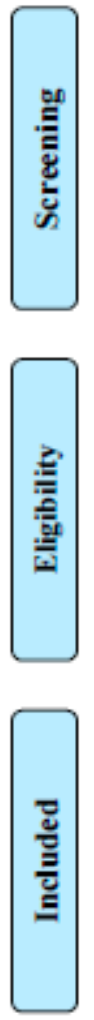

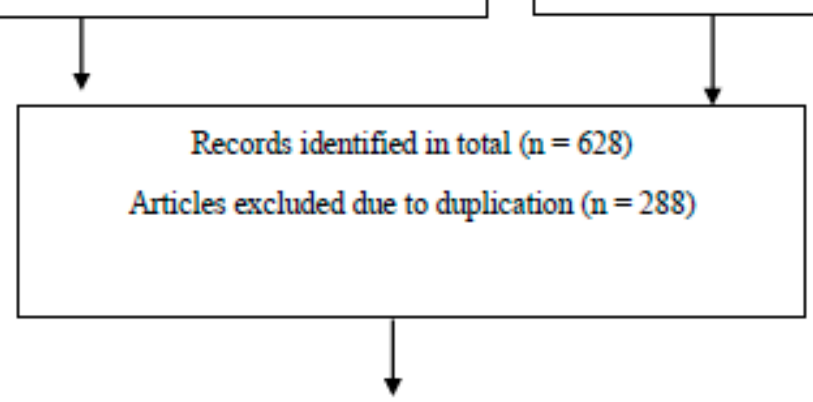

Additional records identified through other sources (Manual Search) $(\mathrm{n}=8)$

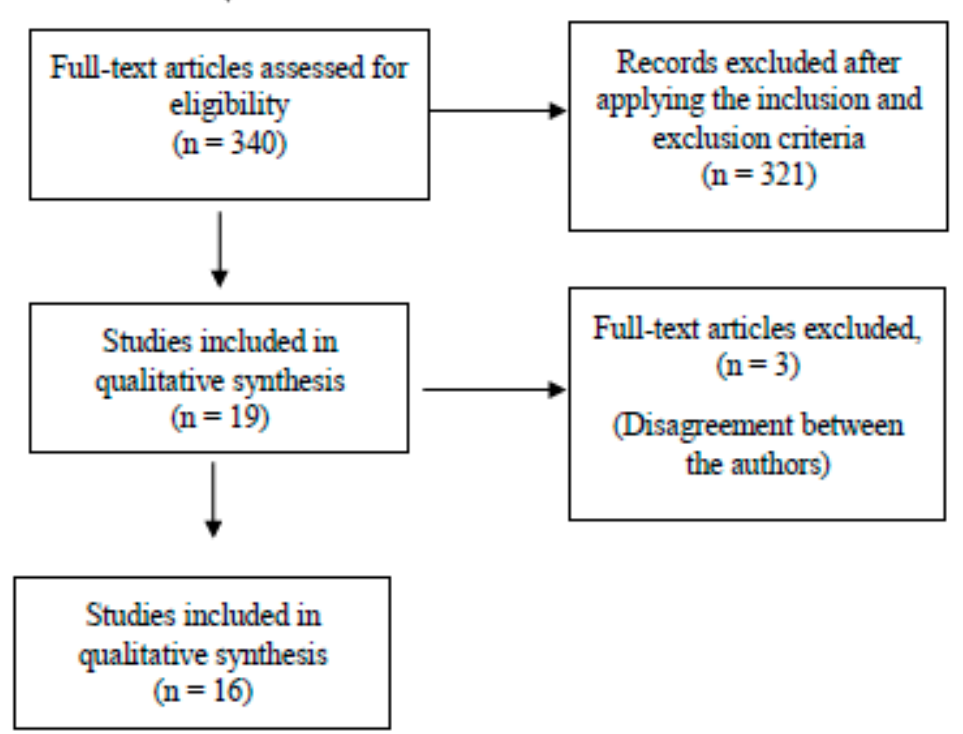

Figure 1. Flow chart for screening and selection of articles.

\section{Results}

Finally, 9 articles were critically analyzed for the extraction of the quantitative data. Most studies reported in the literature revealed that these studies were reported over the last 15 years. The trend showed a gradual increase in the studies reporting on the application of AI for OC diagnosis and the prediction of prognosis.

\subsection{Qualitative Synthesis of the Included Studies}

AI technology has been mainly applied for differentiating between normal, premalignant, and malignant conditions [19-23], predicting the likelihood of oral cancer incidence [24-26], prognosis, early detection of pre-cancerous and cancerous lesions [27-30], predicting the risk of recurrence [31,32], predicting the possibility of disease development from potential malignant lesion, and predicting the survival of patients [33,34].

In this systematic review, 4 studies were reported using convolutional neural networks (CNNs), and another 4 studies were reported using artificial neural networks (ANNs). These neural networks were mainly designed for assessing patient datasets, high-resolution cytology images, hyperspectral images, autofluorescence images (AFI), and white light imaging (WLI) (Table 2). 
Table 2. Details of the studies that have used AI-based models for oral cancer diagnosis and predicting the prognosis.

\begin{tabular}{|c|c|c|c|c|c|c|c|c|c|c|c|c|c|}
\hline Sr. No. & Authors & $\begin{array}{l}\text { Year of } \\
\text { Publication }\end{array}$ & $\begin{array}{c}\text { Algorithm } \\
\text { Architecture }\end{array}$ & Study Design & Objective of the Study & $\begin{array}{l}\text { No. of Im- } \\
\text { ages/Photographs } \\
\text { for Testing }\end{array}$ & Study Factor & Modality & Comparison, If Any & $\begin{array}{l}\text { Evaluation } \\
\text { Accuracy/Average } \\
\text { Accuracy }\end{array}$ & $\begin{array}{c}\text { Results } \\
(+) \text { Effective, } \\
(-) \text { Non Effective } \\
\text { (N) Neutral }\end{array}$ & Outcomes & $\begin{array}{c}\text { Authors } \\
\text { Suggestions/Conclusions }\end{array}$ \\
\hline 1 & $\begin{array}{l}\text { Nayak } \\
\text { et al. [19] }\end{array}$ & 2005 & ANNs & $\begin{array}{l}\text { Cross sectional } \\
\text { study }\end{array}$ & $\begin{array}{c}\text { Discriminating normal, } \\
\text { potentially malignant, and } \\
\text { malignant } \\
\text { conditions using principal } \\
\text { component analysis (PCA) and } \\
\text { artificial neural } \\
\text { network (ANN) }\end{array}$ & 50 & $\begin{array}{l}\text { Differentiating normal, } \\
\text { potentially malignant, } \\
\text { and malignant }\end{array}$ & Recorded spectra & $\begin{array}{l}\text { Principal component } \\
\text { analysis (PCA) }\end{array}$ & $\begin{array}{l}\text { Accuracy } 98.3 \% \text {, } \\
\text { specificitit of } 100 \% \text { and } \\
\text { sensitivity } 96.5 \%\end{array}$ & (+) Effective & $\begin{array}{l}\text { ANN is found to be } \\
\text { slightly better than PCA }\end{array}$ & $\begin{array}{l}\text { This model is efficient } \\
\text { for real-time application. }\end{array}$ \\
\hline 2 & $\begin{array}{l}\text { Tseng } \\
\text { et al. [27] }\end{array}$ & 2015 & ANNs & Cohort study & $\begin{array}{l}\text { ANN for predicting oral cancer } \\
\text { prognosis }\end{array}$ & - & $\begin{array}{l}\text { Determining the } \\
\text { differences between } \\
\text { the symptoms shown } \\
\text { in past cases }\end{array}$ & Datasets & Decision tree (DT) & Not Mentioned & (+) Effective & $\begin{array}{l}\text { Both decision tree and } \\
\text { artificial nueural network } \\
\text { models showed } \\
\text { superiority to the } \\
\text { traditional statistical } \\
\text { model. }\end{array}$ & $\begin{array}{c}\text { Decision tree models are } \\
\text { relatively easier to } \\
\text { interpret compared to } \\
\text { artificial neural network } \\
\text { models. }\end{array}$ \\
\hline 3 & $\begin{array}{l}\text { Uthoff } \\
\text { et al. [28] }\end{array}$ & 2017 & CNN's & $\begin{array}{l}\text { Crosssectional } \\
\text { study }\end{array}$ & $\begin{array}{l}\text { AI-based deep (CNNs) for early } \\
\text { detection of pre-cancerous } \\
\text { and cancerous lesions }\end{array}$ & 170 & $\begin{array}{c}\text { Detection of } \\
\text { pre-cancerous } \\
\text { and cancerous lesions }\end{array}$ & $\begin{array}{l}\text { Autofluorescence } \\
\text { imaging (AFI) and } \\
\text { white light } \\
\text { imaging (WLI) }\end{array}$ & Specialist's diagnosis & $\begin{array}{l}\text { Sensitivities } 85 \%, \\
\text { specificities } 88.75 \%, \\
\text { positive predictive values } \\
87.67 \% \text {, and negative } \\
\text { predictive values } 85.49\end{array}$ & (+) Effective & $\begin{array}{c}\text { CNN achieving high } \\
\text { values of sensitivity, } \\
\text { specificity, PPV, and } \\
\text { NPV compared to the } \\
\text { on-site specialist gold } \\
\text { standard. }\end{array}$ & $\begin{array}{l}\text { Performance should } \\
\text { increase as additional } \\
\text { images are collected. }\end{array}$ \\
\hline 4 & $\begin{array}{l}\text { Shams } \\
\text { et al. [31] }\end{array}$ & 2017 & CNN's & $\begin{array}{l}\text { Cross sectional } \\
\text { comparative } \\
\text { study }\end{array}$ & $\begin{array}{l}\text { Deep Neural Network (DNN) } \\
\text { for predicting the possibility of } \\
\text { oral cancer development in Oral } \\
\text { potentially malignant lesion } \\
\text { patients }\end{array}$ & 10 & $\begin{array}{c}\text { Oral cancer } \\
\text { development in Oral } \\
\text { potentially malignant } \\
\text { lesion patients }\end{array}$ & Datasets & $\begin{array}{c}\text { Support Vector } \\
\text { Machine (SVM), } \\
\text { Regularized Least } \\
\text { Gquares (RSS), } \\
\text { Multi-Layer } \\
\text { Perception (MLP) }\end{array}$ & High accuracy $96 \%$ & (+) Effective & $\begin{array}{l}\text { The results show high } \\
\text { accuracy using DNN than } \\
\text { SVM and MLP }\end{array}$ & None \\
\hline 5 & $\begin{array}{l}\text { Jeyaraj } \\
\text { et al. [30] }\end{array}$ & 2019 & CNN's & $\begin{array}{l}\text { Cross sectional } \\
\text { comparative } \\
\text { study }\end{array}$ & $\begin{array}{l}\text { Deep } \\
\text { learning algorithm for an } \\
\text { automated, computer-aided oral } \\
\text { cancer-detecting system }\end{array}$ & 100 & $\begin{array}{c}\text { Detection of } \\
\text { pre-cancerous as } \\
\text { benign and post } \\
\text { cancerous as } \\
\text { malignant } \\
\text { region }\end{array}$ & $\begin{array}{c}\text { Hyperspectral } \\
\text { images }\end{array}$ & $\begin{array}{l}\text { The traditional } \\
\text { medical image } \\
\text { classification } \\
\text { algorithm }\end{array}$ & $\begin{array}{l}\text { Accuracy of } 91.4 \% \text {, } \\
\text { sensitivity } 9 \% \text { and } \\
\text { specificity of } 91 \%\end{array}$ & (+) Effective & $\begin{array}{l}\text { The quality of diagnosis } \\
\text { is increased by proposed } \\
\text { regression-based } \\
\text { partitioned CNN learning } \\
\text { algorithm for a complex } \\
\text { medical image of oral } \\
\text { cancer diagnosis }\end{array}$ & $\begin{array}{l}\text { This deep learning } \\
\text { the elogorithm can be } \\
\text { easily deployed for } \\
\text { providing an automatic } \\
\text { medical image classifier } \\
\text { without expert } \\
\text { knowledge. }\end{array}$ \\
\hline 6 & $\begin{array}{l}\text { Fahed } \\
\text { Jubair } \\
\text { et al. [20] }\end{array}$ & 2020 & CNN's & $\begin{array}{l}\text { Crosssectional } \\
\text { study }\end{array}$ & $\begin{array}{l}\text { Develop a lightweight deep } \\
\text { CNN using Efficient net-B0 } \\
\text { transfer model CNN for } \\
\text { binary classification of oral } \\
\text { lesions into benign and } \\
\text { malignanto or potentially } \\
\text { malignant } \\
\text { using standard real-time clinical } \\
\text { images }\end{array}$ & 716 & Detecting oral cancer & Clinical images & None & $\begin{array}{c}\text { accuracy } \\
\text { was } 85.0 \% \\
\text { specificity } 84.5 \%, \\
\text { sensitivity } 86.7 \%\end{array}$ & (+) Effective & $\begin{array}{l}\text { AI can improve the } \\
\text { quality and reach of oral } \\
\text { cancer } \\
\text { screening and early } \\
\text { detection. }\end{array}$ & $\begin{array}{c}\text { This model of being smal } \\
\text { in size and } \\
\text { need small computation } \\
\text { powere and memory } \\
\text { capacity. }\end{array}$ \\
\hline 7 & $\begin{array}{l}\text { Sunny } \\
\text { et al. [29] }\end{array}$ & 2019 & ANNs & $\begin{array}{l}\text { Cross sectional } \\
\text { comparative } \\
\text { study }\end{array}$ & $\begin{array}{l}\text { Artificial Neural Network } \\
\text { (ANN) based } \\
\text { risk-straticication model for } \\
\text { early detection of oral } \\
\text { potentially malignant } \\
\text { (OPML)/malignant } \\
\text { lesion. }\end{array}$ & 82 & $\begin{array}{c}\text { Oral potentially } \\
\text { malignant } \\
(\text { OPML)/malignant } \\
\text { lesion. }\end{array}$ & $\begin{array}{l}\text { High-resolution } \\
\text { cytology images }\end{array}$ & $\begin{array}{l}\text { Conventional cytology } \\
\text { and histology }\end{array}$ & $\begin{array}{l}\text { 84-86\%\% Accuracy } \\
\text { Sensitivity } 93 \% \%\end{array}$ & (+) Effective & 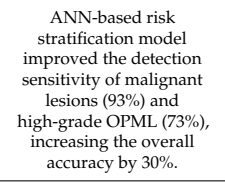 & $\begin{array}{l}\text { This model can be an } \\
\text { invaluable Point-of-Care } \\
\text { (POC) tool for early } \\
\text { detection/screening in } \\
\text { oral cancer. }\end{array}$ \\
\hline 8 & $\begin{array}{l}\text { Jelena } \\
\text { Musulin } \\
\text { et al. [21] }\end{array}$ & 2021 & ANNs & $\begin{array}{l}\text { Cross sectional } \\
\text { comparative } \\
\text { study }\end{array}$ & $\begin{array}{l}\text { Diagnosing OC using the } \\
\text { histological image of a biopsy }\end{array}$ & 322 & Detecting oral cancer & Histological image & $\begin{array}{l}\text { ResNet50, ResNet101 } \\
\text { Cception } \\
\text { MobileNetv2 }\end{array}$ & $\begin{array}{c}\text { Xception and SWT } \\
\text { resulted in the highest } \\
\text { classification } \\
\text { value of } 0.96(\sigma=0.042) \\
\text { AUCmacro }\end{array}$ & (+) Effective & $\begin{array}{l}\text { The AI-based system has } \\
\text { great potential in the } \\
\text { diagnosis of OSCC }\end{array}$ & $\begin{array}{c}\text { This cell shape and size, } \\
\text { pathological mitoses, } \\
\text { tumor-stroma ratio and } \\
\text { the distinction between } \\
\text { early and advanced-stage } \\
\text { OSCCs }\end{array}$ \\
\hline
\end{tabular}


Table 2. Cont.

\begin{tabular}{|c|c|c|c|c|c|c|c|c|c|c|c|c|c|}
\hline Sr. No. & Authors & $\begin{array}{l}\text { Year of } \\
\text { Publication }\end{array}$ & $\begin{array}{l}\text { Algorithm } \\
\text { Architecture }\end{array}$ & Study Design & Objective of the Study & $\begin{array}{l}\text { No. of Im- } \\
\text { ages/Photographs } \\
\text { for Testing }\end{array}$ & Study Factor & Modality & Comparison, If Any & $\begin{array}{c}\text { Evaluation } \\
\text { Accuracy/Average } \\
\text { Accuracy }\end{array}$ & $\begin{array}{c}\text { Results } \\
\text { (+) Effective, } \\
\text { (-) Non Effective } \\
\text { (N) Neutral }\end{array}$ & Outcomes & $\begin{array}{c}\text { Authors } \\
\text { Suggestions/Conclusions }\end{array}$ \\
\hline 9 & $\begin{array}{l}\text { M. } \\
\text { Praveena } \\
\text { Kirubabai } \\
\text { et al. [22] }\end{array}$ & 2021 & $\mathrm{CNN}$ & $\begin{array}{l}\text { Cross sectional } \\
\text { study }\end{array}$ & $\begin{array}{l}\text { To classify } \\
\text { the oral images into either } \\
\text { normal or abnormal images and } \\
\text { diagnosed into } \\
\text { 'Mild' or 'Severe' using a deep } \\
\text { learning algorithm }\end{array}$ & 160 & Detecting oral cancer & Oral images & None & $\begin{array}{c}\text { accuracy } \\
\text { was } 99.7 \% \text {, } \\
\text { 98.6\% of } \\
\text { sensitivity, } 99.1 \% \text { of } \\
\text { specificity, and } 99.7 \%\end{array}$ & (+) Effective & $\begin{array}{l}\text { CNN has high accuracy } \\
\text { in detecting OC }\end{array}$ & None \\
\hline 10 & $\begin{array}{c}\text { Jyoti } \\
\text { Rathod } \\
\text { Ret al. [23] }\end{array}$ & 2019 & CNN's & $\begin{array}{l}\text { Cross sectional } \\
\text { comparative } \\
\text { study }\end{array}$ & $\begin{array}{l}\text { Classify different stages of oral } \\
\text { cancer using machine learning } \\
\text { techniques }\end{array}$ & - & $\begin{array}{c}\text { Diagnosing and } \\
\text { classifying the } \\
\text { premalignant lesion }\end{array}$ & Data set & $\begin{array}{l}\text { SVM, KNN, MLP RSF, } \\
\text { and Logistic } \\
\text { Regression }\end{array}$ & $\begin{array}{l}\text { DT 90.68\%, RSF 91\%, } \\
\text { SVM 88\%, KNN 85\%, } \\
\text { MLP 81\% and Logistic } \\
\text { Regression gives s } 0 \% \text { of } \\
\text { accuracy }\end{array}$ & (+) Effective & $\begin{array}{l}\text { DT and RSF produced the } \\
\text { same accuracy results }\end{array}$ & $\begin{array}{l}\text { classification of oral } \\
\text { cancer can be classified } \\
\text { efficiently with help of } \\
\text { Random Forest and } \\
\text { Decision Tree }\end{array}$ \\
\hline 12 & $\underset{\substack{\text { Kim et al. } \\
[35]}}{\text {. }}$ & 2019 & CNNs & $\begin{array}{l}\text { Retrospective } \\
\text { study }\end{array}$ & $\begin{array}{l}\text { Deep learning-based survival } \\
\text { prediction method in oral } \\
\text { squamous cell carcinoma (SCC) } \\
\text { patients }\end{array}$ & 255 & Survival prediction & Datasets & $\begin{array}{l}\text { Random Survival } \\
\text { Forest (RSF) and the } \\
\text { Cox rpoportional } \\
\text { hazard model (CPH) }\end{array}$ & $\begin{array}{l}c \text {-index of } \\
\text { testing sets reaching } 0.781\end{array}$ & (+) Effective & $\begin{array}{l}\text { This AI model displayed } \\
\text { the best performance } \\
\text { among the three models }\end{array}$ & $\begin{array}{c}\text { This model can be } \\
\text { effective in predicing } \\
\text { with higher accuracy and } \\
\text { can guide clinicians both } \\
\text { in } \\
\text { choosing treatment } \\
\text { options and avoiding } \\
\text { unnecessary treatments }\end{array}$ \\
\hline 13 & $\begin{array}{l}\text { Anwar } \\
\text { Allazmi } \\
\text { et al. [25] }\end{array}$ & 2020 & ANNs & $\begin{array}{l}\text { Crosssectional } \\
\text { study }\end{array}$ & $\begin{array}{l}\text { To develop (ANN) based model } \\
\text { in predicting OC }\end{array}$ & 73 & $\begin{array}{l}\text { Predicting risk of } \\
\text { developing OC }\end{array}$ & Datasets & None & Accuracy of $78.95 \%$ & (+) Effective & $\begin{array}{l}\text { ANN could perform well } \\
\text { in estimating the } \\
\text { probability of malignancy }\end{array}$ & $\begin{array}{l}\text { More cohort studies are } \\
\text { required based on this } \\
\text { model }\end{array}$ \\
\hline 14 & $\begin{array}{l}\text { Chui S. } \\
\text { Chu et al. } \\
\text { [26] }\end{array}$ & 2021 & CNN's & $\begin{array}{l}\text { Cross sectional } \\
\text { comparative } \\
\text { study }\end{array}$ & $\begin{array}{l}\text { To evaluate the ability of } \\
\text { supervised d } \\
\text { machine learning models to } \\
\text { predict disease outcome }\end{array}$ & 467 & $\begin{array}{l}\text { Predicting risk of } \\
\text { developing OC }\end{array}$ & $\begin{array}{c}\text { Clinicopathological } \\
\text { data }\end{array}$ & $\begin{array}{l}\text { linear regression (LR), } \\
\text { DT SVMM, and } \\
\text { k-nearest } \\
\text { neighbors } \\
\text { models } \\
\text { mods) }\end{array}$ & $\begin{array}{l}70.59 \% \text { accuracy (AUC } \\
0.67), 41.98 \% \text { sensitivity, } \\
\text { and a high specificity } \\
\text { of } 84.12 \% \text {. }\end{array}$ & (+) Effective & $\begin{array}{l}\text { CNN's DT model was } \\
\text { most successul in } \\
\text { identifying "rue positive" } \\
\text { progressive } \\
\text { disease }\end{array}$ & $\begin{array}{l}\text { AI models in this study } \\
\text { have shown promise in } \\
\text { predicting } \\
\text { progressive oscCC disease } \\
\text { outcomes }\end{array}$ \\
\hline 15 & $\begin{array}{c}\text { Rosma } \\
\text { et al. [24] }\end{array}$ & 2010 & ANNs & $\begin{array}{l}\text { Cross sectional } \\
\text { comparative } \\
\text { study }\end{array}$ & $\begin{array}{l}\text { Performances of the two } \\
\text { artificial } \\
\text { Intelligent prediction models } \\
\text { when conpared with a group of } \\
\text { oral cancer clinicians. }\end{array}$ & 171 & $\begin{array}{c}\text { Predicting the } \\
\text { likelihood of an } \\
\text { individual developing } \\
\text { oral cancer }\end{array}$ & Datasets & $\begin{array}{l}27 \text { oral cancer } \\
\text { clinicians }\end{array}$ & $\begin{array}{c}\text { Mean accuracy, } \\
\text { sensitivity, and specificity } \\
\text { of the models were } 59.9, \\
45.5, \text { and } 85.3 \text { for fuzzy } \\
\text { nueural } \\
\text { network models; } 63.1, \\
54.2 \text {, and } 78.6 \text { for oral } \\
\text { cancer clinicians } \\
\text { predictions and } 67.5,69.0 \\
\text { and } 64.7 \\
\text { for fuzzzy regression } \\
\text { prediction models. }\end{array}$ & (+) Effective & $\begin{array}{l}\text { Fuzzy regression and } \\
\text { fuzzy neural network } \\
\text { performed better than } \\
\text { oral cancer clinicians }\end{array}$ & $\begin{array}{l}\text { These neural network } \\
\text { models provide a suitable } \\
\text { alternative to human } \\
\text { expert rediction in } \\
\text { predicting oral cancer } \\
\text { susceptibility. }\end{array}$ \\
\hline 16 & $\begin{array}{l}\text { Omar A. } \\
\text { Karadaghy } \\
\text { et al. [32] }\end{array}$ & 2019 & CNN's & $\begin{array}{l}\text { Crosssectional } \\
\text { study }\end{array}$ & $\begin{array}{l}\text { To develop a prediction DT } \\
\text { model using manchine learning } \\
\text { for -5yar overall survival } \\
\text { among patients with OSCC }\end{array}$ & 33,065 & Predicting OSCC & Dataset & None & $\begin{array}{l}\text { accuracy was } 71 \% \text {, } \\
\text { precision was } 71 \% \text {, }\end{array}$ & (+) Effective & $\begin{array}{l}\text { AI better in predicting } \\
\text { OSCC }\end{array}$ & $\begin{array}{l}\text { Al learning may play in } \\
\text { individual patientr risk } \\
\text { estimation in the } \\
\text { the era of big data. }\end{array}$ \\
\hline
\end{tabular}

ANNs: Artificial Neural Networks, CNNs: Convolutional Neural Networks, DNNs: Deep Neural Networks, and c-index: concordance index. 


\subsection{Risk of Bias Assessment and Applicability Concerns}

The QUADAS-2 assessment tool was used for assessing the quality and risk of bias of the included studies (Table S1). Most studies involved using photographic data as an input to the CNNs and ANNs, and hence, $76.47 \%$ of the included studies reported a low risk of bias for the patient-selection domain. However, in four studies, the patient-selection method was unclear. Since the data feeding in AI technology was highly standardized and there was no effect of flow and time frame on the final output, both the factors were categorized in a low-risk group. Nayak et al. used histopathology as the gold standard and studies by Tseng et al., Alabi et al., and Kim et al., were based on the prognostic outcome of the OSCC patients $[19,27,33,34]$. Hence, the reference standard in this situation was graded as low risk. Reference standard and the flow and timing domain were unclear in $17.64 \%$ and $29.41 \%$, respectively. Hence, in this paper, a low risk of bias was reported in the index test $(100 \%)$ and $(70.58 \%)$ the inflow and timings. Under the risk of a bias arm of the QUADAS-2 tool, the applicability concern arms also showed $88.23 \%$ and $47.05 \%$ low risk of bias in the index test and the reference standard. However, patient selection and index test domain were unclear for $35.29 \%$ and $11.76 \%$ (Table S2, and Figures 2 and 3).

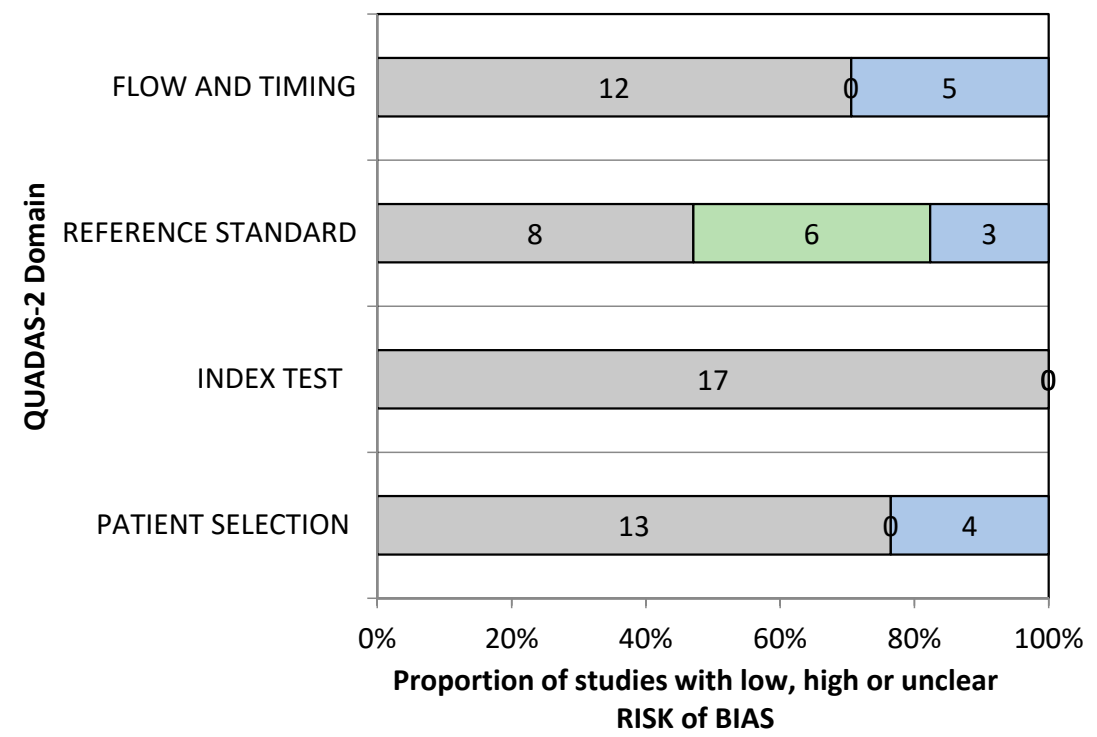

Figure 2. QUADAS-2 assessment of the individual risk of bias domains.

$\square$ Low $\square$ High $\square$ Unclear

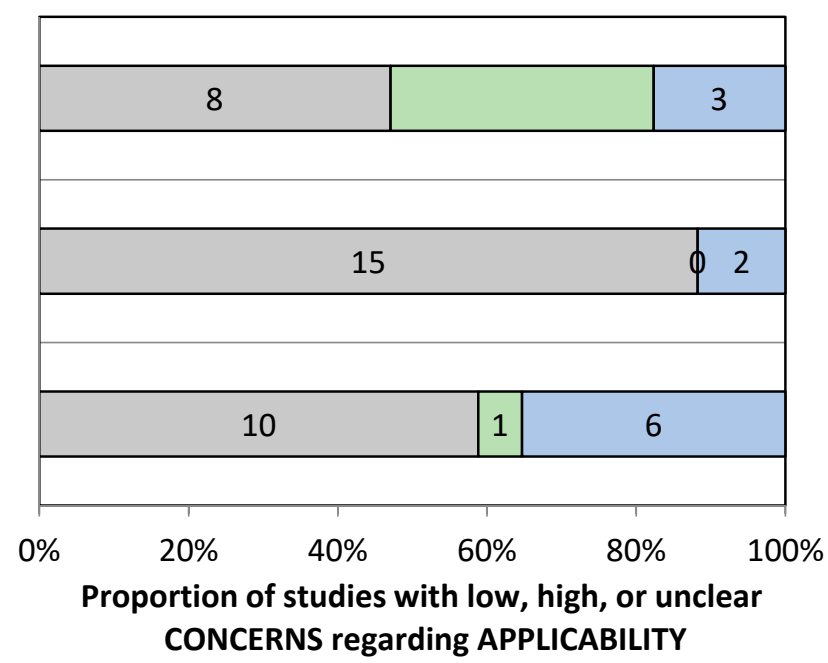

Figure 3. QUADAS-2 assessment of applicability concerns. 


\section{Discussion}

Oral cancer is one of the most prevalent cancer with high mortality, and it is a significant public health issue. Late diagnosis and high death rates are attributes of cancer around the world. According to the 2015 statistics of World Health Organization (WHO), cancer is the first or the second driving reason of death in almost 91 of 172 countries. The diagnosis and prediction of the reoccurrence of OC are the challenging factors, as AI involves complex data on etiology and risk factors [35-37].

$\mathrm{AI}$ is an exceptionally fresh development with a significant prognostic power, which allows clinicians to select appropriate treatment modalities. AI holds an incredible guarantee to empower clinicians to make noteworthy choices, depending on the immense amount of digitized data. Previous studies have applied machine-learning methods to huge patient datasets for early diagnosis and predicting the risk of occurrence of OC.

AI has a more preferred advantage over existing techniques for detecting OC. It is a versatile innovation and can acquire additional information at any time. As AI calculations get information from new patients, they can merge this information into their dynamic datasets to improve their prescient exhibition and can reduce the burden of treatment and cost for patients [38]. There are two types of AI technologies, artificial neural networks (ANN) and convolution neural networks (CNN). The significant difference between the two is that in CNN, only the last layer of a neuron is completely associated. While in ANN, every neuron is associated with each different neuron [39]. This paper expects to examine the performance of these AI-based models that have reported on the diagnosis and prediction of the risk of occurrence of OC.

\subsection{Artificial Intelligence in Detecting and Diagnosing Oral Cancer}

As the late-stage disease has poor prognosis, early detection is important in OC patients. The data obtained from cytology images, fluorescent images, CT images, and depth of invasion can be used in AI learning tools, and OC can be diagnosed quickly with more accuracy. From our collected list of articles, 6 articles reported the application of AI-based computerized models for diagnosing OC. Several studies have carried out early detection of the advanced stage of OC and studies have reported that OC arise from different subsites of the oral cavity such as tongue, buccal mucosa, etc. This heterogeneity of oral malignant growth makes it difficult to be analyzed.

Sunny et al. conducted a study by ANN for early detection of OC, using tele cytology (TC), which is digitization of the cytology slides [29]. The efficacy of AI was compared with conventional cytology and histology; 11,981 prepossessed images were loaded for AI analysis, based on the risk stratification model. Results showed an accuracy of 80-84\% in diagnosis, with no difference in tele cytology and conventional cytology detection, however, potentially malignant oral lesions were detected with low sensitivity, using tele cytology. The ANN-based model showed improved malignant detection accuracy to 93\%, and a potentially malignant lesion to $73 \%$. The study used the brush biopsy method for sample collection, which is less invasive, and this factor should also be considered while detecting cancer.

Jeyaraj et al. conducted a study in which OC was diagnosed based on a regressionbased deep-learning algorithm for the characterization of oral malignant growth [30]. A deep-learning algorithm of $\mathrm{CNN}$ was developed in a computer-aided OC detecting system and 100 hyperspectral images (HIS) were analyzed. They observed a $91.4 \%$ sensitivity in detecting cancerous lesions using the regression-based algorithm, and the results were compared to the traditional algorithm using the same images. The quality of diagnosis was improved for the proposed model of the algorithm, as compared to the conventional.

Uthoff et al. conducted a study on detecting OC by using smartphone-based images and AI technology [28]. Based on the concept of point of care, smartphone-based images were developed. Autofluorescence and white light imaging were added to the pictures, and these pictures were stacked to AI algorithms for recognizing oral malignancy. A sum of 170 autofluoresced pictures was taken. This strategy was very convenient for 
application, and the accuracy was improved. However, the study needs to be conducted on a large population for further validation. A similar study was done by Nayak et al., using autofluorescent spectral images, and analysis was done using principal component analysis (PCA) and ANN [19]. PCA is computing based on principal components of data and the results from ANN performance was slightly better than the PCA. The advantage of this technique was that fluorescence spectroscopy image uses a minimally invasive technique and there is no need for biopsy [27,40]. In a study conducted by Musulin et al., AI showed better results in detecting OC, by using Histology images [21]. Similarly, in a study conducted by Kirubabai et al., CNN was better at differentiating malignant lesions as mild or severe, by using clinical images of patients [22].

Kann et al. applied deep-learning machines on 106 OC patients for the identification of nodal metastasis and tumor extra-nodal extension involvement [17]. The dataset comprised 2875 CT (computerized tomography) segmented lymph node samples. This study explored the capability of the deep-learning model to assist head and neck cancer patient management. For DNN, the area under the receiver operating characteristic curve (AUC) showed 0.91, which implied a higher accuracy. AUC represents the two-dimensional areas under the receiver operating characteristic curve (ROC). Similarly, Chang et al., reported an AUC of 0.90 for predicting the occurrence of OC, using AI based on genome markers [41]. In this study, logistic regression analysis was used to compare with AI. However, the study was conducted on 31 patients, which is a considerably less sample size, a study on a larger number of patients has to be carried out for better analysis.

\subsection{Artificial Intelligence in Predicting the Occurrence of Oral Cancer}

Currently, OC is treated with advanced treatment aids, however, the reoccurrence rate of $\mathrm{OC}$ is very high. Treatment of oral malignant growth relies on the stage of the disease. Lack of an evidence-on staging system may prompt deficient or pointless treatment. Different prognostic biomarkers and restorative targets have been proposed in ongoing periods, but they are not reproduced in the present cancer staging system. To date traditional statistical methods have been used for predicting OC, for example, cox proportional hazard $(\mathrm{CPH})$, and it is not suitable for predicting conditions like OC.

Considering the complex 'dataset' of oral carcinoma, an AI-based anticipation prediction will give satisfied outcomes. Previous studies that used AI for predicting OC yielded excellent results $[34,42,43]$.

Alabi et al. conducted a study on 311 patients in Brazil which compared four machinelearning algorithms in predicting the risk of reoccurrence of oral tongue squamous cell carcinoma [33]. These different machine-learning AI-based algorithms were based on support vector machine (SVM), naïve Bayes (NB), boosted decision tree (BDT), and decision forest (DF). All these algorithms showed improved accuracy in diagnosis, but the BDT algorithm showed the highest accuracy. However, the study included fewer samples, and more external algorithm data is required.

Shams et al. employed AI with the gene expression profile, to predict the occurrence of OC and also the transformation of oral potentially malignant lesions [31]. The study was conducted on 86 subjects, among them, 51 subjects developed OC and 31 subjects remained without malignancy. The study compared SVM, DNN, and multi-layer perception (MLP). Excellent results were obtained by deep-learning machines with $96.5 \%$ accuracy and $94 \%$ accuracy was obtained with MLP [43].

Chui et al., predicted the occurrence of cancer, based on clinical, pathological data, and compared linear regression (LR), BDT, SVM, and k-nearest neighbors (KNN) models, and concluded that BDT was the best model [26].

Tseng et al. determined the difference between symptoms exhibited by demised and survived OC patients [27]. The performance was compared between conventional logistic regression, decision tree, and ANN, and was conducted on 674 OC patients. Study used prognostic factors such as survival rate, death, cancer occurrence, and metastasis. The 
study concluded that the decision tree was easy to interpret and accuracy of the decision tree, and ANN was compared more to conventional logistic regression.

Rosma et al. tested the effectiveness of AI in predicting cancer based on the risk habits and demographic profiles in a Malaysian cohort [24]. Prediction of OC was compared between fuzzy regression model, fuzzy neural network prediction model, and clinician opinion. Fuzzy regression provides means when there is a lack of data and also provides a relationship between explanatory and response variables. The AI-based neural network and fuzzy regression model performed better in accuracy than human opinion, in predicting the OC.

\section{Conclusions}

$\mathrm{AI}$ is more accurate in diagnosing oral cancer as compared to the conventional method of diagnosis. Retrospective clinical data of patients may help in improving the AI-based diagnosis. Additionally, AI-based algorithms showed more accurate results in predicting the OC occurrence. More data and studies are needed to conduct AI-based algorithms to predict OC. The treatment of OC will not be effective if they are diagnosed at a later stage. Subsequently, early recognition techniques are required. The complex etiology and high recurrence rate make the investigation difficult. The patients can be classified as highand low-risk groups, using accurate data from $\mathrm{AI}$, which helps clinicians in planning and treatment, as compared to conventional methods. Patients can be directed with sensible advice and the clinicians can be guided with informed decisions.

Supplementary Materials: The following are available online at https: / www.mdpi.com/article / 10.3390/diagnostics11061004/s1, Table S1: Quality assessment (QUADAS 2) summary of the risk of bias; Table S2: Quality assessment (QUADAS 2) summary of applicability concerns.

Author Contributions: Conceptualization, S.B.K., and S.V.; methodology, S.N.; software, S.V.; validation, S.P., L.T. and A.Z.; formal analysis, A.A.A.K.; investigation, P.C.M.; resources, Y.A.; data curation, G.S.S.; writing—original draft preparation, A.A.A.K.; writing—review and editing, S.M.; visualization, S.C.S.; supervision, S.P.; project administration, S.P. All authors have read and agreed to the published version of the manuscript.

Funding: This is a non-funded research and there has been no financial support for this work that could have influenced its outcome.

Data Availability Statement: Data is contained within the article.

Conflicts of Interest: The authors declare no conflict of interest.

\section{References}

1. World Health Organization. WHO Report on Cancer: Setting Priorities, Investing Wisely and Providing Care for All; Technical Report; World Health Organization: Geneva, Switzerland, 2020.

2. Sinevici, N.; O'sullivan, J. Oral cancer: Deregulated molecular events and their use as biomarkers. Oral Oncol. 2016, 61, 12-18. [CrossRef]

3. Lewin, F.; Norell, S.; Johansson, H.; Gustavsson, P.; Wennerberg, J.; Biörklund, A.; Rutqvist, L. Smoking Tobacco, Oral Snuff, and Alcohol in the Etiology of Squamous Cell Carcinoma of the Head and Neck: A Population-Based Case-Referent Study in Sweden. Cancer 1998, 82, 1367-1375. [CrossRef]

4. Ilhan, B.; Lin, K.; Guneri, P.; Wilder-Smith, P. Improving Oral Cancer Outcomes with Imaging and Artificial Intelligence. J. Dent. Res. 2020, 99, 241-248. [CrossRef] [PubMed]

5. Dhanuthai, K.; Rojanawatsirivej, S.; Thosaporn, W.; Kintarak, S.; Subarnbhesaj, A.; Darling, M.; Kryshtalskyj, E.; Chiang, C.P.; Shin, H.I.; Choi, S.Y.; et al. Oral cancer: A multicenter study. Med. Oral Patol. Oral Cir. Bucal 2018, 23, e23-e29. [CrossRef] [PubMed]

6. Lavanya, L.; Chandra, J. Oral Cancer Analysis Using Machine Learning Techniques. Int. J. Eng. Res. Technol. $2019,12,596-601$.

7. Kearney, V.; Chan, J.W.; Valdes, G.; Solberg, T.D.; Yom, S.S. The application of artificial intelligence in the IMRT planning process for head and neck cancer. Oral Oncol. 2018, 87, 111-116. [CrossRef] [PubMed]

8. Hamet, P.; Tremblay, J. Artificial intelligence in medicine. Metabolism. 2017, 69, S36-S40. [CrossRef]

9. Kaladhar, D.; Chandana, B.; Kumar, P. Predicting Cancer Survivability Using Classification Algorithms. Books 1 View project Protein Interaction Networks in Metallo Proteins and Docking Approaches of Metallic Compounds with TIMP and MMP in Control of MAPK Pathway View project Predicting Cancer. Int. J. Res. Rev. Comput. Sci. 2011, 2, 340-343. 
10. Kalappanavar, A.; Sneha, S.; Annigeri, R.G. Artificial intelligence: A dentist's perspective. Pathol. Surg. 2018, 5, 2-4. [CrossRef]

11. Krishna, A.B.; Tanveer, A.; Bhagirath, P.V.; Gannepalli, A. Role of artificial intelligence in diagnostic oral pathology-A modern approach. JOMFP 2020, 24, 152-156.

12. Kareem, S.A.; Pozos-Parra, P.; Wilson, N. An application of belief merging for the diagnosis of oral cancer. Appl. Soft Comput. J. 2017, 61, 1105-1112. [CrossRef]

13. Arbes, S.J. Factors contributing to the poorer survival of black Americans diagnosed with oral cancer (United States). Cancer Causes Control 1999, 10, 513-523. [CrossRef]

14. de Melo, G.M.; Ribeiro, K.; Kowalski, L.; Deheinzelin, D. Risk Factors for Postoperative Complications in Oral Cancer and Their Prognostic Implications. Arch. Otolaryngol. Head Neck Surg. 2001, 127, 828-833.

15. Bànkfalvi, A.; Piffkò, J. Prognostic and predictive factors in oral cancer: The role of the invasive tumour front. J. Oral Pathol. Med. 2000, 29, 291-298. [CrossRef] [PubMed]

16. Schliephake, H. Prognostic relevance of molecular markers of oral cancer-A review. Int. J. Oral Maxillofac. Surg. 2003, 32, 233-245. [CrossRef] [PubMed]

17. Kann, B.H.; Aneja, S.; Loganadane, G.V.; Kelly, J.R.; Smith, S.M.; Decker, R.H.; Yu, J.B.; Park, H.S.; Yarbrough, W.G.; Malhotra, A.; et al. Pretreatment Identification of Head and Neck Cancer Nodal Metastasis and Extranodal Extension Using Deep Learning Neural Networks. Sci. Rep. 2018, 8, 1-11. [CrossRef] [PubMed]

18. Whiting, P.F.; Rutjes, A.W.S.; Westwood, M.E.; Mallett, S.; Deeks, J.J.; Reitsma, J.B.; Leeflang, M.M.G.; Sterne, J.A.C.; Bossuyt, P.M.M. Quadas-2: A revised tool for the quality assessment of diagnostic accuracy studies. Ann. Intern. Med. 2011, 155, 529-536. [CrossRef]

19. Nayak, G.S.; Kamath, S.; Pai, K.M.; Sarkar, A.; Ray, S.; Kurien, J.; D'Almeida, L.; Krishnanand, B.R.; Santhosh, C.; Kartha, V.B.; et al. Principal component analysis and artificial neural network analysis of oral tissue fluorescence spectra: Classification of normal premalignant and malignant pathological conditions. Biopolymers 2006, 82, 152-166. [CrossRef] [PubMed]

20. Jubair, F.; Al-karadsheh, O.; Malamos, D.; Al Mahdi, S.; Saad, Y.; Hassona, Y. A novel lightweight deep convolutional neural network for early detection of oral cancer. Oral Dis. 2021, 1-8. [CrossRef]

21. Musulin, J.; Štifanić, D.; Zulijani, A.; Ćabov, T.; Dekanić, A.; Car, Z. An enhanced histopathology analysis: An ai-based system for multiclass grading of oral squamous cell carcinoma and segmenting of epithelial and stromal tissue. Cancers 2021, 13, 1784. [CrossRef]

22. Kirubabai, M.P.; Arumugam, G. View of Deep Learning Classification Method to Detect and Diagnose the Cancer Regions in Oral MRI Images. Med. Legal Update 2021, 21, 462-468.

23. Rathod, J.; Sherkay, S.; Bondre, H.; Sonewane, R.; Deshmukh, D. Oral Cancer Detection and Level Classification Through Machine Learning. Int. J. Adv. Res. Comput. Commun. Eng. 2020, 9, 177-182. [CrossRef]

24. Rosma, M.D.; Sameem, A.K.; Basir, A.; Siti Mazlipah, I.; Norzaidi, M.D. The use of artificial intelligence to identify people at risk of oral cancer: Empirical evidence in Malaysian university. Int. J. Sci. Res. Educ. 2010, 3, 10-20.

25. Alhazmi, A.; Alhazmi, Y.; Makrami, A.; Masmali, A.; Salawi, N.; Masmali, K.; Patil, S. Application of artificial intelligence and machine learning for prediction of oral cancer risk. J. Oral Pathol. Med. 2021, 1-7. [CrossRef]

26. Chu, C.S.; Lee, N.P.; Adeoye, J.; Thomson, P.; Choi, S. Machine learning and treatment outcome prediction for oral cancer. J. Oral Pathol. Med. 2020, 49, 977-985. [CrossRef] [PubMed]

27. Tseng, W.T.; Chiang, W.F.; Liu, S.Y.; Roan, J.; Lin, C.N. The Application of Data Mining Techniques to Oral Cancer Prognosis. J. Med. Syst. 2015, 39, 59-66. [CrossRef] [PubMed]

28. Uthoff, R.D.; Song, B.; Sunny, S.; Patrick, S.; Suresh, A.; Kolur, T.; Keerthi, G.; Spires, O.; Anbarani, A.; Wilder-Smith, P.; et al. Point-of-care, smartphone-based, dual-modality, dual-view, oral cancer screening device with neural network classification for low-resource communities. PLoS ONE 2018, 13, 1-21. [CrossRef] [PubMed]

29. Sunny, S.; Baby, A.; James, B.L.; Balaji, D.; N. V., A.; Rana, M.H.; Gurpur, P.; Skandarajah, A.; D'Ambrosio, M.; Ramanjinappa, R.D.; et al. A smart tele-cytology point-of-care platform for oral cancer screening. PLoS ONE 2019, 14, 1-16. [CrossRef]

30. Jeyaraj, P.R.; Samuel Nadar, E.R. Computer-assisted medical image classification for early diagnosis of oral cancer employing deep learning algorithm. J. Cancer Res. Clin. Oncol. 2019, 145, 829-837. [CrossRef] [PubMed]

31. Shams, W.K.; Htike, Z.Z. Oral Cancer Prediction Using Gene Expression Profiling and Machine Learning. Int. J. Appl. Eng. Res. 2017, 12, 4893-4898.

32. Karadaghy, O.A.; Shew, M.; New, J.; Bur, A.M. Development and Assessment of a Machine Learning Model to Help Predict Survival among Patients with Oral Squamous Cell Carcinoma. JAMA Otolaryngol. Head Neck Surg. 2019, 145, 1115-1120. [CrossRef] [PubMed]

33. Alabi, R.O.; Elmusrati, M.; Sawazaki-Calone, I.; Kowalski, L.P.; Haglund, C.; Coletta, R.D.; Mäkitie, A.A.; Salo, T.; Almangush, A.; Leivo, I. Comparison of supervised machine learning classification techniques in prediction of locoregional recurrences in early oral tongue cancer. Int. J. Med. Inform. 2020, 136, 104068. [CrossRef] [PubMed]

34. Kim, D.W.; Lee, S.; Kwon, S.; Nam, W.; Cha, I.H.; Kim, H.J. Deep learning-based survival prediction of oral cancer patients. Sci. Rep. 2019, 9, 1-10. [CrossRef] [PubMed]

35. Warnakulasuriya, S. Global epidemiology of oral and oropharyngeal cancer. Oral Oncol. 2009, 45, 309-316. [CrossRef]

36. Gupta, N.; Gupta, R.; Acharya, A.K.; Patthi, B.; Goud, V.; Reddy, S.; Garg, A.; Singla, A. Changing Trends in oral cancer-A global scenario. Nepal J. Epidemiol. 2017, 6, 613-619. [CrossRef] 
37. Dhage, S.N. A Review on Early Detection of Oral Cancer using ML Techniques. Int. J. Sci. Prog. Res. 2019, 158, 1-5.

38. Chan, C.H.; Huang, T.T.; Chen, C.Y.; Lee, C.C.; Chan, M.Y.; Chung, P.C. Texture-Map-Based Branch-Collaborative Network for Oral Cancer Detection. IEEE Trans. Biomed. Circuits Syst. 2019, 13, 766-780. [CrossRef]

39. Bur, A.M.; Holcomb, A.; Goodwin, S.; Woodroof, J.; Karadaghy, O.; Shnayder, Y.; Kakarala, K.; Brant, J.; Shew, M. Machine learning to predict occult nodal metastasis in early oral squamous cell carcinoma. Oral Oncol. 2019, 92, 20-25. [CrossRef]

40. Kan, C.W.; Nieman, L.T.; Sokolov, K.; Markey, M.K. AI in clinical decision support: Applications in optical spectroscopy for cancer detection and diagnosis. Stud. Comput. Intell. 2008, 107, 27-49. [CrossRef]

41. Chang, S.W.; Abdul-Kareem, S.; Merican, A.F.; Zain, R.B. Oral cancer prognosis based on clinicopathologic and genomic markers using a hybrid of feature selection and machine learning methods. BMC Bioinform. 2013, 14, 170-185. [CrossRef] [PubMed]

42. Lucheng, Z.; Wenhua, L.; Meng, S.; Hangping, W.; Juan, W.; Xuebang, Z.; Changlin, Z. Comparison between artificial neural network and Cox regression model in predicting the survival rate of gastric cancer patients. Biomed. Rep. 2013, 1, 757-760. [CrossRef]

43. Zheng, B.; Yoon, S.W.; Lam, S.S. Breast cancer diagnosis based on feature extraction using a hybrid of K-means and support vector machine algorithms. Expert Syst. Appl. 2014, 41, 1476-1482. [CrossRef] 